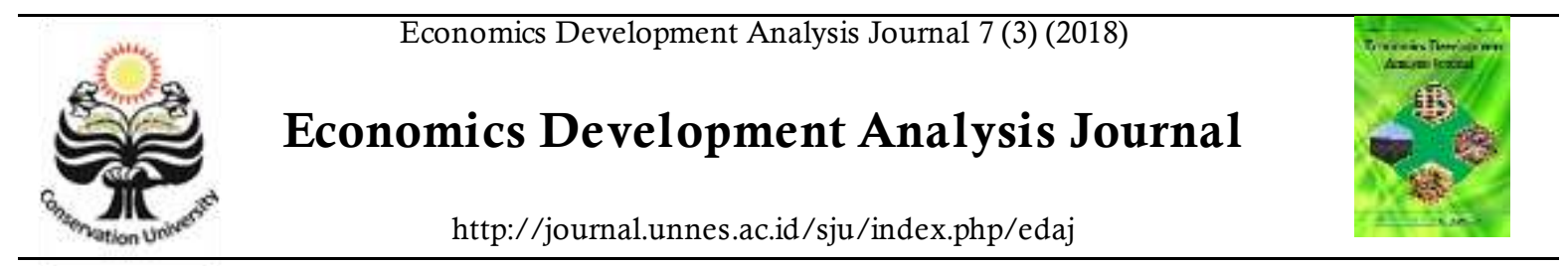

\title{
Human Resources Planning Strategy at Vocational High School in Tegal Regency
}

\author{
Kurniasih $^{1 凶}$, Dyah Maya Nihayah ${ }^{2}$ \\ Economics Development Department, Economics Faculty, Universitas Negeri Semarang
}

\section{Info Artikel}

Sejarah Artikel:

Receipted April 2018

Accepted June 2018

Published August 2018

\begin{abstract}
The manufacturing is the sector with the highest contribution to GRDP in Tegal regency. However, thenumber of industries reflected in the industrialization process cannot absorb labor in the labor market. Unemploymentin Tegal regency is ranked highest in Central Java with unemployment rates dominated by graduatesofVocational High School (SMK). Therefore, the purpose of this research is to formulate the strategy of human resource planning at SMK in Kabupaten Tegal. The method used in this research is a qualitative descriptivemethodwith the Analytical Hierarchy Process (AHP) tool. The variables used in this study are human resources; amenitie; institutions and bureaucracy; and partnerships. The results of the study using AHP indicate that the criteriaof education personnel are the most priority aspects. Then the next aspects that need to be considered or becomea priority are the innovative curriculum management, student placement of $P K L$ and the need to adjusttheneeds of industry with the competence of expertise. Based on these priorities, in the effort of human resourceplanning at SMK in Tegal regency need improvement of education, curriculum innovation relevant to thebusinessworld and industry so that existing graduates become competent and competitive graduates.
\end{abstract}

Keywords: Human Resource, Planing, Vocational High School

${ }^{\star}$ Corresponding Author:

Journal Room, Building L2, FE UNNES, Sekaran Campus,

Gunungpati, Semarang 50229, Indonesia

E-mail: edajunnes@mail.unnes.ac.id 


\section{INTRODUCTION}

Unemployment is one of the important issues of the Sustainable Development Goals initiated by the United Nations Development Program in 2015. The problem of unemployment is increasingly important because it is one of the causes of poverty (Wibisono, 2015). Unemployment is also an economic and social problem that must be overcome (Prajasa, 2013). The industrial sector can help reduce the unemployment rate because it is considered capable of increasing employment availability and can spur economic growth (Mahendra, 2014).

Tegal Regency as one of the industrial cities in Central Java has economic characteristics that are dominated by the manufacturing industry sector which can be seen from the Gross Regional Domestic Product (GRDP). Of the seventeen types of business fields recorded by the Tegal Regency Statistics Agency, the processing industry ranks first in its contribution to GRDP. In 2010 the contribution of the manufacturing industry sector ranked first with a percentage of 26.82 percent and always increased every year. In 2016 the contribution of the processing industry reached 33.43 percent of the GRDP of Tegal Regency.

The number of workers absorbed in the processing industry sector ranks second with a percentage of 23.84 percent of the total number of people who work or as much as 76,124 after large and retail trade; and repair of cars and motorbikes. This identifies that there is a great opportunity for the entry of labor in this sector because of the high added value that can be seen from the high contribution of this sector to the GRDP of Tegal Regency even though the industry has less than the wholesale and retail trade; and repair of cars and motorbikes.

According to the Central Bureau of Statistics, the percentage of unemployed people in Tegal Regency ranks first with a percentage of 9.52 percent. When compared with the average number of unemployed people in Central Java Province at 4.99 percent, the number of unemployed in Tegal Regency is quite high. Existing unemployment is dominated by SMK graduates with a percentage of 21.18 percent or as many as 12,693 people.

Based on these data it can be concluded that the unemployment structure in Tegal Regency is dominated by the educated unemployed. Educated unemployment can be caused by a lack of alignment with education development planning and the development of employment opportunities that are not in accordance with the majors taken at the school level or mismatch (Manti, Husaini, Mujahidin, \& Hafidhuddin, 2016).

This condition causes new problems considering the purpose of vocational school is to print workers who are ready to work. But the fact is that vocational high school graduates only become the second largest contributor to unemployment in Tegal regency. Vocational education provided in secondary schools can reduce the risk of unemployment in the first years because it provides high-skilled school graduates who can be directly applied to the workplace (Lavrijsen \& Nicaise, 2017). The number of Vocational Schools compared to the Senior High Schools in Tegal Regency is more vocational schools with a ratio of 71:29 percent. The number of SMK in Tegal Regency is 64 schools while there are only 26 high schools.

Based on the publication of the Ministry of Industry of the Republic of Indonesia in the Planning of Industrial Human Resource Needs in the Framework of Acceleration of Industrialization in 2012-2014, one of the problems faced in relation to labor in the industrial sector is the quality of Human Resources both general and vocational high school graduates generally do not meet or not in accordance with the needs of the industry, especially to fill the middle-level worker position that is usually produced by vocational school graduates. In addition to the processing, the Ministry of Industry also said that although the vocational curriculum is more relevant to the needs of employment compared to high schools, 
in reality, it is not specific enough to meet industry needs.

Whereas to be accepted to work in a place one must fulfill the qualifications that are used as conditions such as education standards, minimum qualifications, appearance, expertise, skills, and talents (Farhanah \& Azizah, 2013). This can be seen in Figure 1.1, where accreditation for expertise competencies in Vocational Schools in Tegal Regency is dominated by a $B$ value of 59.2 percent. While the competence of expertise with an A score of only 23.9 percent.

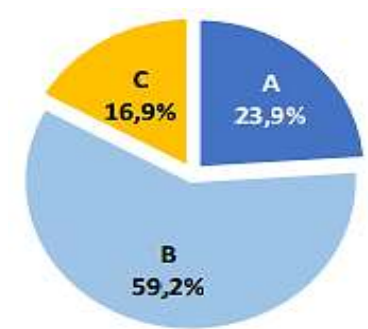

Figure 1. Accreditation Value of Vocational Skills Competencies in Tegal Regency

Source: BAN-SM, 2016

Based on the Basic Data of Primary and Secondary Education in 2018, there were some imbalances between the ratio of teachers to students in several districts in Tegal Regency. The highest ratio is occupied by Margasari sub district with a total of 81 teachers, teaching students 1,908 with a ratio of $1: 24$. When viewed from the average ratio between teachers and students in Tegal District, it is 1:19, which means that one teacher has as many as 19 students. Whereas according to Government Regulation Number 74 of 2008 concerning Teachers Article 17 stipulates that the ratio between teachers and students at a good vocational level is $1: 15$, which means that one teacher holds 15 students. In addition, judging from the value of the teacher competency test results in SMK, it shows that the competence of vocational teachers is of a lower value compared to other levels of school such as elementary, junior high and high school. The results of the competency test for vocational teachers only get a score of 59.30 lower than the results of the teacher competency test at the provincial level.

In addition to teaching staff as human resources available in schools, schools also need to consider the facilities that must be provided when opening new skills, such as classrooms and practice rooms. Based on Figure 2, it can be seen for SMKs that 446 classrooms are in good condition, 500 classrooms are in a slightly damaged condition and 13 classrooms are in badly damaged condition. When compared to high schools, the percentage of the number of high school classrooms with good conditions is more than that of SMK.

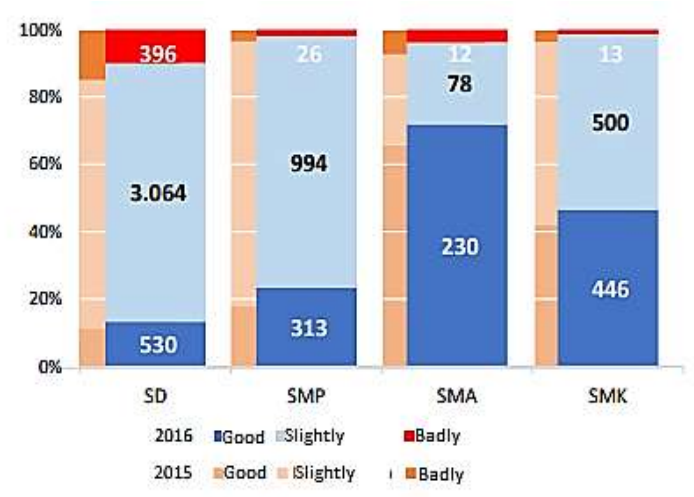

Figure 2. The condition of Classroom Facilities for Elementary Schools, Middle Schools, High Schools and Vocational Schools in Tegal Regency

Source: Regional Education Balance of Tegal Regency, 2016

Policies directed at increasing certain specialties must be possessed by workers in accordance with regional characteristics and needs of the production sector to avoid mismatches in the labor market (Nihayah \& Kusumantoro, 2010). Adjustment between the world of education and regional potential also becomes important because it will have an impact on optimizing the management of Human Resources which in turn can increase economic growth, demand for labor which can reduce unemployment (Ngadi, 2014). Based on these problems the purpose of this study was to find out the Human Resource planning strategies in Vocational Schools in Tegal Regency as one of 
the efforts to reduce the number of unemployed from SMK graduates.

\section{RESEARCH METHODS}

The research method used in this study is a qualitative research method to determine the factors that influence vocational school in determining the competence of expertise and planning human resources in vocational schools in Tegal regency in an effort to reduce the number of unemployed in the education sector. Variations in the method used are using interview techniques, questionnaire, observation or observation, documentation and data processing information with statistics.

To answer the research questions selected key persons or informants using purposive sampling technique. This non-probability sampling is a method where researchers choose key persons randomly based on their unique character or experience, attitudes, and perceptions (Cooper \& Schindler, 2017). The key persons in this study are: (1) State Vocational High School 2 Slawi, (2) State Vocational High School 2 Adiwerna, (3) Islamic University Adiwerna, (4) Muhammadiyah Slawi Vocational School, (5) Tegal District Bappeda, and (6) Education Agency and Central Java Province Culture.

Table 1. Pairwise Appeal Scale

\begin{tabular}{cl}
\hline Value & \multicolumn{1}{c}{ Definition } \\
\hline 1 & $\begin{array}{l}\text { One goal with another is } \\
\text { equally important } \\
\text { One goal is slightly more } \\
\text { important (rather strong) } \\
\text { than the other } \\
\text { One goal is more } \\
\text { important than other } \\
\text { goals } \\
\text { One goal is very } \\
\text { important compared to } \\
\text { other goals } \\
\text { One goal is absolutely } \\
\text { important compared to } \\
\text { other goals } \\
\text { The middle value is } \\
\text { between two adjacent } \\
\text { consideration values }\end{array}$ \\
\hline
\end{tabular}

Source: Saaty in Mufid (2014)
Data analysis method used in this study is Analitycal Hierarchy Process (AHP). The variables used in this study are arranged in a hierarchy or priority. This analysis is based on the pairwise matrix comparison, namely the criteria which are the judgment of the decision maker rather than pair against a criterion. Comparison between one criterion against another criterion is done by using paired pairing scale numbers. The scale given explains the value of 1 to 9 which is determined as a consideration to compare one criterion with the other criteria or an alternative criterion with each other.

The paired appeal scale used in the preparation of Human Resource planning for Vocational Schools in Tegal Regency can be seen in Table 1.

The preparation of criteria and alternative criteria as an alternative to determine policy priorities with Analytical Hierarchy Process (AHP) are used variables from aspects of Human Resources, facilities, institutions and bureaucracy and partnerships.

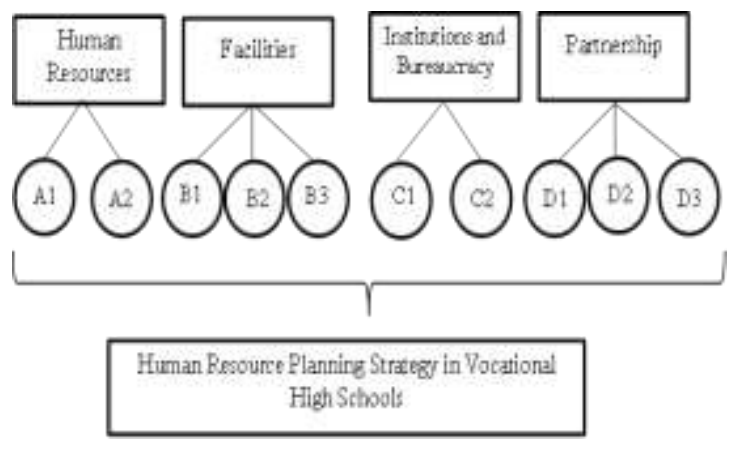

Figure 3. AHP Criteria and Alternatives

The Human Resource Criteria are derived into two alternative criteria, namely (1) the quantity and quality of educational staff competency skills in the industrial sector (A1) and (2) the ability of students to understand the material (A2). Facility criteria are reduced to three alternative criteria, namely (1) completeness of learning facilities (B1), (2) completeness and condition of building learning spaces both material and practical (B2), and (3) curriculum management and innovative teaching programs. Whereas for institutional and 
bureaucratic criteria are derived into two alternative criteria, namely (1) management and leadership of the Principal (C1) and (2) synergy between related institutions and agencies (C2). The partnership criteria were then derived into three alternative criteria, namely (1) building partners or collaborating with the related industrial world through apprenticeship (D1), (2) forming cooperation through adjusting industry needs with expertise competency curriculum (D2), and (3) forming cooperation through scholarship distribution (D3)

\section{RESULTS AND DISCUSSION}

Human Resource Planning, especially in Vocational Schools, can be done by arranging planning based on the priority scale. The purpose of setting policy priorities is to achieve competent educational goals in the world of work. This study illustrates how the criteria that are a priority in determining policies, especially to print Human Resources or competent SMK graduates in accordance with the industrial sector as the leading sector of Tegal Regency. The results of the questionnaires that have been processed using Analytical Procurement Hierarchy with 9 expert choice programs produce strategies based on priority criteria which can be seen in Figure 4.

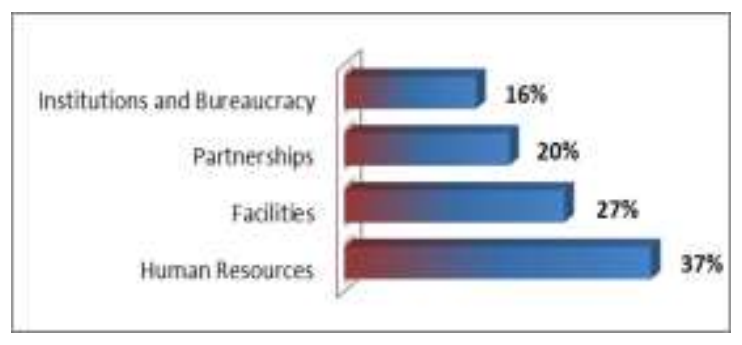

Figure 4. Priority Criteria for HR Planning for Vocational Schools in Tegal Regency Source: Primary Data Processed, 2018

Based on Figure 4, we can see that the criteria that are prioritized in planning Human Resources in Vocational Schools in Tegal Regency are Human Resources. Human Resources are the most priority criteria with a score of 37.2 percent. Human Resources are considered to be one of the most influential factors when forming Human Resources in accordance with development goals. Whether or not Human Resources competencies are influenced by Human Resources who educate Human Resources. In other words, to print competent students, schools need to have competent educators.

The second priority criterion for printing Human Resources for competent SMK graduates is the facility criteria. Based on Figure 5, the facility criteria show a priority score of 26.7 percent. Facilities provided by the school have a great influence on students' competence after the Human Resources themselves. Students as Human Resources printed by every Vocational School in Tegal Regency have the right to get the facilities that meet. The existing facilities in Vocational Schools in Tegal Regency themselves are already standard SNI. Almost every SMK has a practice room and workshop for certain departments.

The third priority criteria after Human Resources and facilities in Human Resource planning in Vocational Schools in Tegal Regency is a partnership. Based on data processing using Analytical Process Hierarchy with 9 expert choice programs, the partnership has a score of 20 percent. This score is greater than the institutional and bureaucratic criteria that only have a score of 16 percent. This shows that partnerships are considered more important to be concerned than institutions and bureaucracy.

Viewed from the institutional and bureaucratic side, the existing Vocational Schools in Tegal Regency know enough about the flow of bureaucracy related to the establishment of new Vocational Schools and in opening new skills competencies. However, the adjustment of inter-agency policies has not been going well, especially in the education sector. From some opinions of the deputy headmaster of the academic field, to open a new department, especially in the industrial sector requires a fairly thorough preparation of many aspects, both from the education staff, the file to the financing. From the results of the study using Analytical Hierarchy Process with expert choice 9 program, 
the inconsistency ratio results in 0.03 which means that the answers given by key persons are

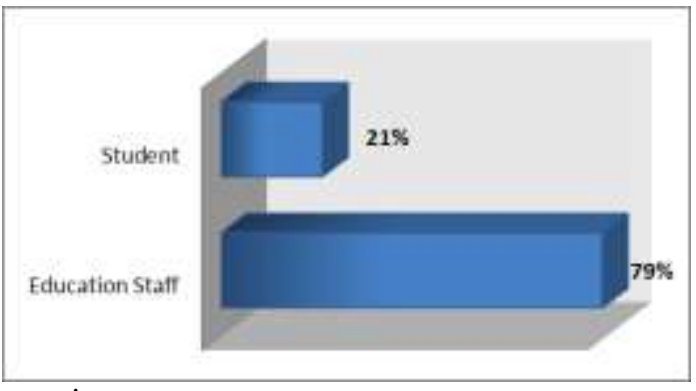

consistent.

Figure 5. Alternative Criteria for Human Resources

Source: Primary Data Processed, 2018

Based on the results of Analytical Hierarchy Process with expert choice program 9 in Figure 4.3, the alternative criteria that became a priority in human resource planning in vocational schools in Tegal regency in the criteria of human resources are the quantity and quality of educational staff competency expertise in the industrial sector. The results of data processing show that the quantity and quality of educational staff competency skills have a higher score than the alternative criteria of students' ability to understand the material, which is 79 percent and 21 percent respectively. The quantity and quality of educators are considered more important because whether or not Human Resources competencies are printed depending on the educators themselves. While the ability of students to understand the material can be adjusted in line with the teaching and learning process. From the results of the study using Analytical Hierarchy Process with 9 expert choice program, the inconsistency ratio was 0.00 which meant that the answers given by key persons were consistent.

Based on the results of the Analytical Hierarchy Process with the 9 expert choice program in Figure 5, the alternative criteria that became a priority in Human Resource planning in Vocational Schools in Tegal Regency in the facility criteria were innovative curriculum management and teaching programs with a score of 44.7 percent. Whereas for the alternative criteria of completeness and condition of the study room building (material and practice) and the completeness of the learning facilities

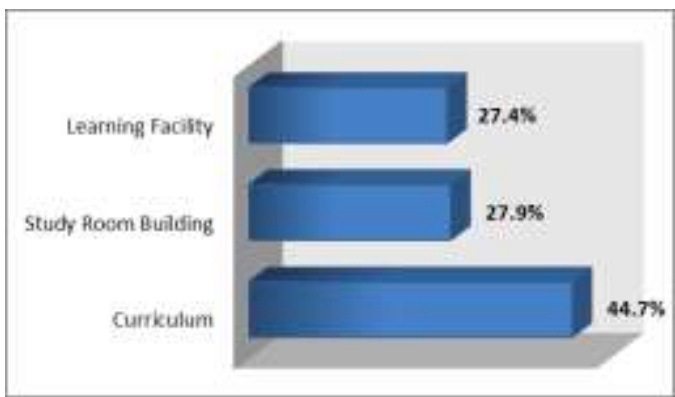

respectively 27.9 percent and 27.4 percent.

Figure 6. Alternative Criteria for Facilities

Source: Primary Data Processed, 2018

The score between the completeness of the building's facilities and conditions is not too different, it is only 0.5 percent different. This is because between suggestions and buildings become a compliment or complement between one another. From the results of the study using Analytical Hierarchy Process with 9 expert choice program, the inconsistency ratio was 0.00 which meant that the answers given by key persons were consistent.

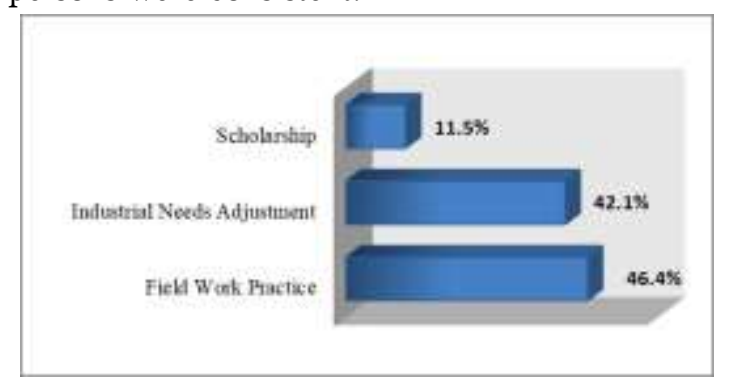

Figure 7. Alternative Partnership Criteria

Source: Primary Data Processed, 2018

Based on the results of the Analytical Hierarchy Process with the expert choice program 9 in Figure 7, the alternative criteria that are prioritized in planning Human Resources in Vocational Schools in Tegal Regency in partnership criteria are to build partners or collaborate with the related industrial world through apprenticeship placement with scores 46.4 percent. Whereas for the alternative criteria to form cooperation through scholarship distribution and form cooperation through adjusting the needs of the industry with the expertise competency curriculum each has a 
score of 11.5 and 42.1 percent. Between apprenticeship or PKL with the adjustment of industry needs, the score range is not too far, which is 2.3 percent. This is because between the two alternative criteria are interrelated where the school must adjust the needs of the business world and the industrial world in determining the decision to open competency expertise, especially in the industrial sector to support the ease of placement of street vendors.

Whereas for alternative scholarship criteria only get a low score of 11.5 percent. Based on the results of the program, several Vocational Schools in Tegal Regency stated that the scholarship that entered the school was felt to be very lacking. Not all schools can get scholarship assistance from business partners in the form of financial assistance and equipment to support the teaching and learning process. So, from this condition, existing Vocational Schools in Tegal Regency only focus on how to make graduates who are printed can be absorbed in the labor market. From the results of the study using Analytical Hierarchy Process with 9 expert choice program, the inconsistency ratio was 0.00 which meant that the answers given by key persons were consistent.

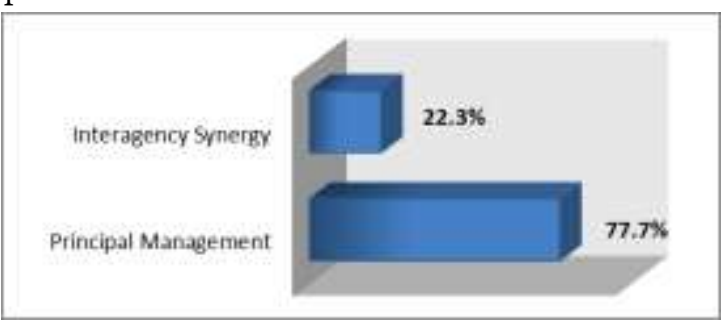

Figure 8. Alternative Institutional and Bureaucratic Criteria

Source: Primary Data Processed, 2018

Based on the results of the Analytical Hierarchy Process with the expert choice program 9 in Figure 8, the alternative criteria that became a priority in Human Resource planning in Vocational Schools in Tegal Regency in institutional and bureaucratic criteria were principals' leadership management with a score weight of 77.7 percent. Whereas for alternative synergistic criteria between related institutions and agencies only gained a score weight of 22.3 percent. Principal leadership management is considered more important in planning Human Resources in Vocational Schools in Tegal Regency. From the results of interviews that have been conducted, some schools focus more on internal school factors than external factors. The leadership management of the principal will later determine the direction of the school's policy, related to the decision to open new skills competencies, whether to be adjusted to the related service or with the trends in the community. From the results of the study using Analytical Hierarchy Process with 9 expert choice program, the inconsistency ratio was 0.00 which meant that the answers given by key persons were consistent.

In planning Human Resources in Vocational Schools in Tegal Regency in this study four criteria were used which were then reduced to 10 alternative criteria. These alternative criteria explain in more detail which alternative criteria are prioritized in human resource planning. The existence of a score weight that arises from the results of data processing with the Analytical Hierarchy Process does not mean that one criterion is not important to be noticed. But with this weighting, it will be able to know which criteria or alternative criteria need to be prioritized to achieve goals, in this case, Human Resource planning in Vocational Schools in Tegal Regency which is in accordance with the industrial sector of Tegal Regency.

Based on the results of Analytical Hierarchy Process with the expert choice program 9 in Figure 9, the alternative criteria that became a priority in Human Resource planning in Vocational Schools in Tegal Regency were the quantity and quality of educational staff competency skills in the industrial sector with a score of 21.8 percent. The next alternative criteria after education personnel that need to be prioritized in a row are innovative curriculum management and teaching programs with a score weight of 15.6 percent, building partners or collaborating with the related industrial world through apprenticeship placement with a score of 11.7 percent, up to the last alternative criterion with the lowest score weight that is forming a 
partnership through scholarship distribution of 2.7 percent.

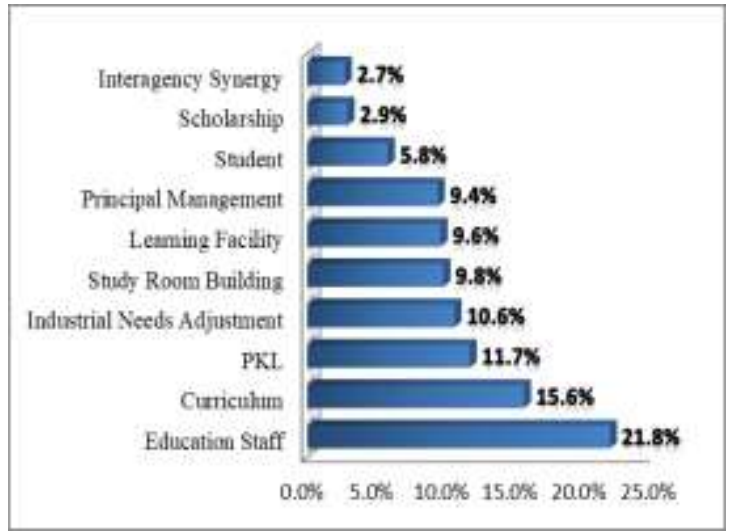

Figure 9. Alternative Order of Human Resource Planning in Vocational Schools in Kab. Tegal Source: Primary Data Processed, 2018

The quantity and quality of educational staff competency expertise in the industrial sector in Vocational Schools in Tegal Regency itself need to get more attention given the lack of teachers who are competent in expertise competencies that support the industrial sector. Most educators who support this leading sector are educators who are competent in the machinery industry. For other skill competencies such as metal processing, textile products, the manufacturing industry is still lacking. It can be seen that there are only two Vocational Schools that open competency skills in the metal processing industry, namely SMK N 2 Adiwerna and SMK N 1 Adiwerna. To support the planning of Human Resources in Vocational Schools in Tegal Regency to suit the leading industries of Tegal Regency, it is necessary to pay attention to the quantity and quality of education personnel that is in accordance with the sector.

As the heart of vocational schools, curriculum management and innovative teaching programs need to get special attention after education personnel. Whether or not graduates are printed will depend on how curriculum planning is carried out in each vocational school. Curriculum planning, especially in planning the opening of new skills competencies, there are still many vocational schools that use the trend of the community as a material consideration. This can be seen in the results of the AHP which shows that the synergy between institutions occupies the last rank where 5 out of 6 key persons taken by the questionnaire state that principals' leadership management is more important than the synergy between institutions. This finding is also consistent with the statement of the Tegal District Bappeda, that in the field of education the new Bappeda focuses on how to increase school participation and reduce illiteracy, not to the extent of alignment between Bappeda policies and competency skills in SMK in Tegal Regency.

\section{CONCUSION}

In preparing Human Resources planning for Vocational Schools in Tegal Regency to suit the industrial sector, there are three alternative criteria that become the highest priority, namely the provision of education personnel with a score of 21.8 percent, the preparation of a curriculum with a score of 15.6 percent and cooperation through the placement of street vendors with score 11.7 percent. Whereas for the three alternative criteria with a low priority score that is students' understanding in understanding the material that is 5.8 percent, cooperation through scholarship distribution is 2.9 percent and the synergy between institutions is 2.7 percent.

A deeper assessment is needed when deciding on the competency of the expertise to be disclosed from the aspect of skills competency absorption in the labor market. So that existing graduates have high employment opportunities and do not cause an increase in the unemployment rate.

\section{REFERENCES}

Cooper, D. R., \& Schindler, P. S. (2017). Metode Penelitian Bisnis Edisi 12 Buku 1. Jakarta: Salemba Empat.

Farhanah, L., \& Azizah, R. (2013). Optimalisasi Penyerapan Tenaga Kerja Indonesia melalui Pengembangan Human Capital dan Penyediaan Jariangan Kerja Online yang Terintegrasi Secara Nasional. Economics Development Analysis Journal.

Lavrijsen, J., \& Nicaise, I. (2017). Return on Vocational Education Over the Life Cycle: Between Immediate Labour Market 
Preparation and Lifelong Employability. International Review of Education, 1-24.

Mahendra, A. D. (2014). Analisis Pengaruh Pendidikan, Upah, Jenis Kelamin, Usia dan pengalaman Kerja Terhadap Produktivitas Tenaga Kerja (Studi di Industri Kecil Tempe di Kota Semarang). Semarang: Universitas Diponegoro.

Manti, B. B., Husaini, A., Mujahidin, E., \& Hafidhuddin, D. (2016). Konsep Pendidikan Modern Mahmud Yunus dan Kontribusinya Bagi Lembaga Pendidikan Islam di Indonesia. International Journal of Islamic Educataion, 23-55.

Mufid, A. (2014). Sistem Pendukung Keputusan Penilaian Proposal Kegiatan PNPM MPd Menggunakan Metode Profile Matching dan Analytic Hierarchy process (AHP). Jurnal Sistem Informasi Bisnis.

Ngadi. (2014). Relevansi pendidikan Kejuruan Terhadap Pasar Kerja di Kota Salatiga. Jurnal Kependudukan Indonseia.

Nihayah, D. M., \& Kusumantoro. (2010). Penentu Upah Regional: Tenaga Kerja Terdidik (Skilled Labor) dan Tidak Terdidik(Unskilled Labor) di Indonesia. JEJAK, 28-39.

Prajasa, M. H. (2013). Pangaruh Investasi Asing, Jumlah Penduduk dan Inflasi terhadap Pengagguran Terdidik di Jawa Tengah Periode Tahun 1980-2011. Economics Development Analysis Journal.

Wibisono, R. Y. (2015). Analisis Pengaruh PDRB, Pengangguran dan Pendidikan Terhadap Kemiskinan di Jawa Tengah Tahun 20082013. Semarang: Universitas Diponegoro. 